\title{
Numerical simulation of detached breakwaters for mangrove restoration in Bengkalis Island, Indonesia
}

\author{
Mubarak ${ }^{l}$, Sigit Sutikno ${ }^{2 *}$, Alvin Defarian ${ }^{2}$, Keisuke Murakami ${ }^{3}$, and Koichi Yamamoto ${ }^{4}$ \\ ${ }^{1}$ Department of Marine Science, Universitas Riau, Pekanbaru, Indonesia \\ ${ }^{2}$ Department of Civil Engineering, Universitas Riau, Pekanbaru, Indonesia \\ ${ }^{3}$ Department of Civil and Environmental Engineering, University of Miyazaki, Miyazaki, Japan \\ ${ }^{4}$ Department of Civil and Environmental Engineering, Yamaguchi University, Japan
}

\begin{abstract}
This paper presents the application of detached breakwater to reduce wave energy for protecting mangrove planting site. Initial planting of mangroves still needs seawater for their growth, but they will be distracted by the big wave. How is the detached breakwater should be designed for this purpose is the objective of this research. This research simulated the wave propagation at the existing condition and under some alternative designs of detached breakwater to find out the optimum design of detached breakwater for mangrove planting site. The CADMAS-SURF is a numerical model that was used for the simulation. Bengkalis coast in Indonesia was picked up as study area of this research. The mangrove degradation and the severe coastal abrasion have occurred in this area for long period. The simulation result shows that in the high tide condition, the wave height and wave velocity at the mangrove plantation area are about $1.12 \mathrm{~m}$ and $3.86 \mathrm{~m} / \mathrm{s}$ respectively in the case of the existing condition. In this case, the initial mangrove plantation cannot be applied because it will be destroyed by the wave. By applying breakwater both for rubble mound type and vertical wall type, the wave height and the wave velocity were reduced to $0.69 \mathrm{~m}, 2.39 \mathrm{~m} / \mathrm{s}$ and $0.72 \mathrm{~m}, 2.31 \mathrm{~m} / \mathrm{s}$ respectively. In this case, the initial mangrove plantation can be applied because it will not be destroyed by the wave.
\end{abstract}

\section{Introduction}

The islands of Riau province which are located at Malacca strait, are mostly covered with peatland as presented in Fig. 1a [1]. Because of the coastal peatlands are a fragile ecosystem [2], those islands are very vulnerable against coastal erosion. Coastal erosion has been occurring continuously at the coast facing to the Malacca Strait at least for the past 30 years. Temporal LANDSAT image analysis clarified that the peatland area decreased at about 160 ha/year in the Riau Province on average because of the coastal erosion (Fig. 1b) [3]. In the extreme case, the coastal setback in Bengkalis Island, one of the Riau Islands is up to $30 \mathrm{~m} /$ year $[4,5]$. This coastal peat erosion endangers the local community life and

*Corresponding author: ssutiknoyk@yahoo.com 
plantation activity in the coastal area and is recognized to the Bengkalis Regency, Riau Province. The main cause is thought to be the mangrove degradation after the 1960's by the human activity. The coastal erosion is enhanced by the bog-burst [6]. The bog-burst is one kind of peat failure. It happens in the wet season, when the unusual high groundwater table maintained because the waterways of the plantation are constructed near the coastline, and the water level is maintained high for oil palm bunch transportation. The coastline setback endangers the coastal communities as well as agricultural activities.

On the other hands, there were some sedimentation areas that mangroves were formed naturally behind the peat bar [7]. The primary cause is thought to be the hydrodynamical process in the Bengkalis coastal zone. This kind of process should be studied to understand the mangrove restoration in the coastal area. Restoration of mangrove ecosystem is very important in the degraded coastal zone because of the erosion. Planting mangrove directly in the coastal area is not easy since the wave propagation from Malacca Strait is relatively high. Initial planting of mangroves still need seawater for their growth, but they will be distracted by the big wave. Using structural countermeasure, such as detach breakwater is one of an alternative to reduce the wave energy but they still get the sea water for their life $[8,9]$. The objective of this research is how to design the detached breakwater.

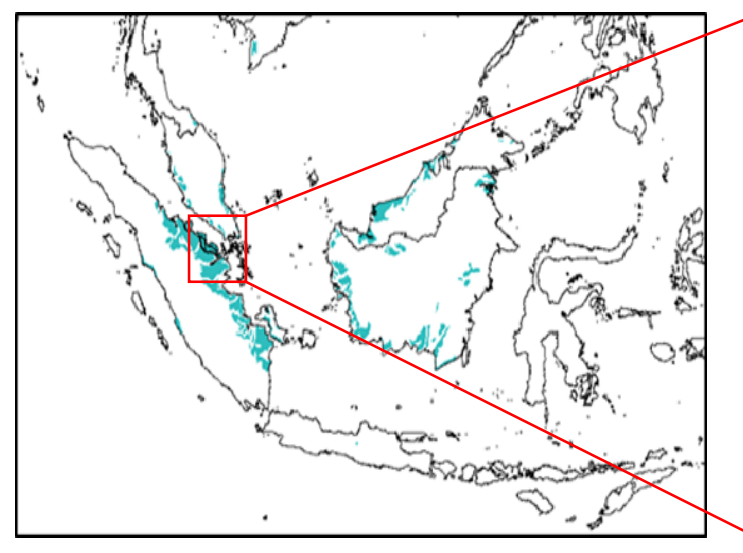

(a)

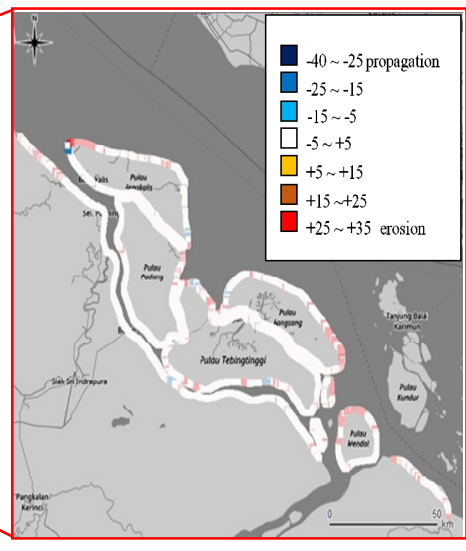

(b)

Fig. 1. Peat distribution of SE Asia (a) [1] and Annual average Erosion/ Propagation rate in Riau Province, Indonesia [3].

\section{Methodology}

\subsection{Study area}

This study was focused at Bengkalis coastal area as presented in Fig. 2. The island is almost flat and has the maximum surface elevation of approximately $10-15 \mathrm{~m}$ above sea level. The area is facing directly to the Malacca Strait which has strong waves and currents at certain times. The aerial photo shows the degrade mangroves at the coastal area. Initially, the top layer of the area was peatland with the thickness varied from 3 to $4 \mathrm{~m}$. Those layers have already lost by the erosion process by leaving the alluvial layer as shown in Fig. 2.

The mechanism of peat lost in this area has been studied [4]. After the land-use change significantly from peat swamp forest to palm oil plantation in the west part of Bengkalis Island, the water balance in this area have not been well distributed in time and space. Many canals have been made for plantation purpose that has been made this area easy 
dried. This made the water table lower, and peat material in the surface became dry especially in the dry season. When the rainy season comes, the precipitation will increase the mass of the peat soil through increasing the water content. This reduced the stability of peat slopes that caused peat failure. Peat failure in the coastline area generated a movement amount of peat material to the coastal area. These peat materials were easily transported by current drift because these peats were relatively light material.
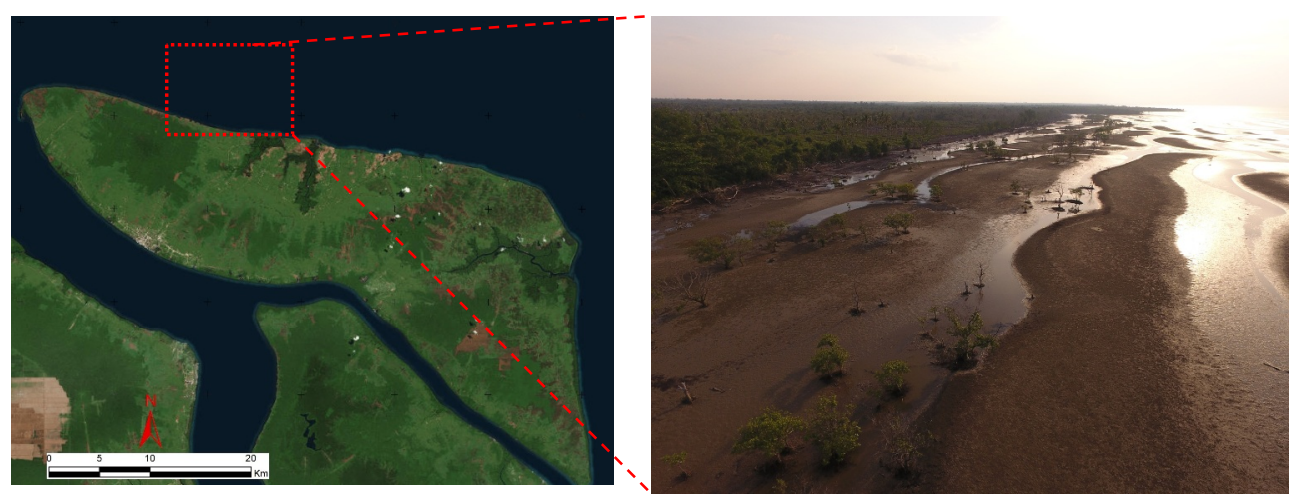

Fig. 2. Study area and aerial photo of Bengkalis Island, Riau Province, Indonesia.

\subsection{Numerical model}

This research simulated the wave propagation at the existing condition and under some alternative designs of the detached breakwater to find out the optimum design of detached breakwater for mangrove planting site. The CADMAS-SURF is a numerical model that was used for the simulation. The numerical model has been widely used for wave simulation for any kind or purposes [10-13]. The basic equations in this direct numerical simulation are the continuity equation and momentum equation, known as the Navier-Stokes equations. This study employs a system of such equations, discretized with the finite difference method to simulate wave propagation at the coastal zone.

The governing equations consisted of a continuity equation, Navier-Stokes equation in $\mathrm{x}$ and $\mathrm{z}$-direction and an advection equation for tracing the temporal water surface elevation, as shown in Eq (1)-(6). The last equation includes the function, $\mathrm{F}(\mathrm{x}, \mathrm{z}, \mathrm{t})$, which means the ratio of water volume in each numerical cell.

$$
\begin{gathered}
\frac{\partial \gamma_{x} u}{\partial x}+\frac{\partial \gamma_{z} w}{\partial z}=S_{p} \\
\lambda_{v} \frac{\partial u}{\partial t}+\frac{\partial \lambda_{x} u u}{\partial x}+\frac{\partial \lambda_{z} w u}{\partial z}=-\frac{\gamma_{v}}{\rho} \frac{\partial p}{\partial x}+\frac{\partial}{\partial x}\left\{\gamma_{x} v_{e}\left(2 \frac{\partial w}{\partial x}\right)\right\} \\
+\frac{\partial}{\partial z}\left\{\gamma_{z} v_{e}\left(\frac{\partial u}{\partial z}+\frac{\partial w}{\partial x}\right)\right\}-D_{x} u+S_{u}-R_{x} \\
\lambda_{v} \frac{\partial w}{\partial t}+\frac{\partial \lambda_{x} u w}{\partial x}+\frac{\partial \lambda_{z} w w}{\partial z}=-\frac{\gamma_{v}}{\rho} \frac{\partial p}{\partial z}+\frac{\partial}{\partial z}\left\{\gamma_{z} v_{e}\left(2 \frac{\partial w}{\partial z}\right)\right\} \\
+\frac{\partial}{\partial x}\left\{\gamma_{x} v_{e}\left(\frac{\partial w}{\partial x}+\frac{\partial u}{\partial z}\right)\right\}-D_{z} u+S_{w}-R_{z}-\gamma_{v} g \\
\gamma_{v} \frac{\partial F}{\partial t}+\frac{\partial \gamma_{x} u F}{\partial x}+\frac{\partial \gamma_{z} w F}{\partial z}=S_{F}
\end{gathered}
$$


where $t$ means the time, $x$ and $z$ mean the horizontal and vertical coordinate. Also, $p$ means the pressure, $u$ and $w$ mean the horizontal and vertical velocity components, respectively. $\rho$ is the density of the fluid, $v$ is the summation of molecular kinematic viscosity and eddy kinematic viscosity, $g$ is the gravity acceleration, $v \gamma$ is the volume porosity, $\gamma x$ and $\gamma z$ are the aerial of porosity components, $S F, S u$ and $S w$ are wave generation source, $D x$ and $D z$ are the coefficients for sponge layer, and $R x$ and $R z$ are the resistant components due to porosity in $\mathrm{x}$ and $\mathrm{z}$-axis.

\subsection{Numerical simulation}

Numerical simulations were conducted under the highest high-water level (HHWL) and mean sea level (MSL) condition. The breakwater type used in this study are caisson, trapezium, and without breakwater. Scenario-1, Scenario-2, and Scenario-3 are the simulations under HHWL condition using breakwater caisson type, trapezium type, and without breakwater respectively. Furthermore, Scenario-4, Scenario-5, and Scenario-6 are the simulations under MSL condition using breakwater caisson type, trapezium type, and without breakwater respectively. The scenarios of this simulation are presented in Table 1.

Table 1. Scenario for wave simulation.

\begin{tabular}{|c|c|c|}
\hline Scenario & Breakwater type & Tidal condition \\
\hline Sc-1 & No breakwater & \multirow{2}{*}{ Highest High Water Level (HHWL) } \\
\hline Sc-2 & Trapezium type & \\
\hline Sc-3 & Vertical wall type & \\
\hline Sc-4 & No breakwater & \multirow{2}{*}{ Mean Sea Level (MSL) } \\
\hline Sc-5 & Trapezium type & \\
\hline Sc-6 & Vertical wall type & \\
\hline
\end{tabular}

The data for numerical simulation were bathymetry, wind, tide, and beach material. The geometry of the simulation was constructed based on the measurement of topography dan bathymetry of the research area, as shown in Fig. 3. The measurement point was located at Point A, which is about $150 \mathrm{~m}$ from the beach where the mangrove seeding located.

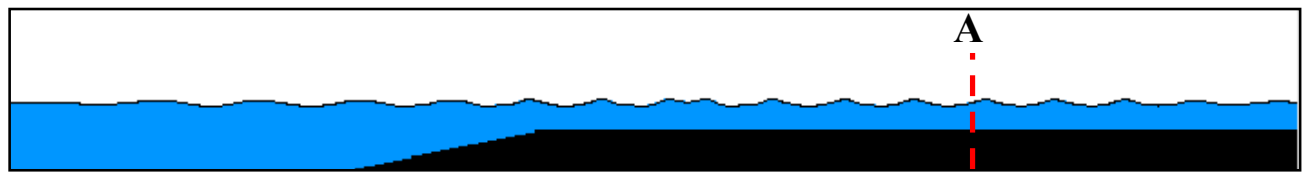

Fig. 3. The geometry of the simulation, constructed from Bengkalis coast, Riau Province, Indonesia.

\section{Results and discussion}

\subsection{Input Data for numerical simulation}

Some important data for input on numerical simulation are the wave, tide, and wind. The wind data were recorded from SESAME system installed by Yamaguchi UniversityUniversity of Riau-Polytechnic Bengkalis. The data used in this study recorded from 
January $1^{\text {st }}, 2015$ to December $31^{\text {st }}, 2015$. The data were analyzed, and presented in the form of wind rose as shown in Fig. 4.

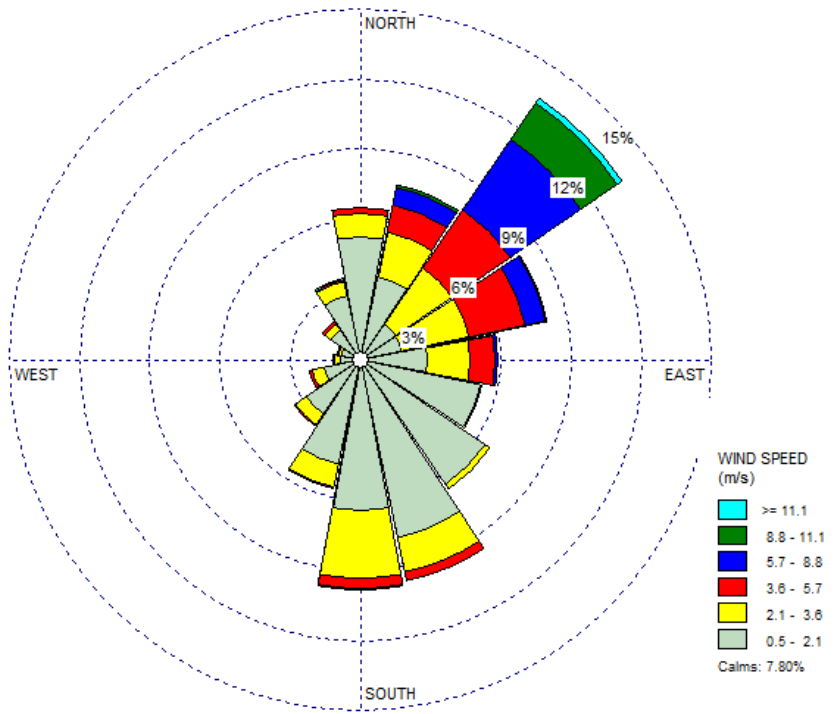

Fig. 4. The wind rose of the Bengkalis area in 2015.

Bengkalis sea level tides used for tidal analysis are measurement data obtained from the Hydrographic Center and Navy-Marine Oceanography, Indonesian Army on August 22nd to September 5th, 2015. The data were analyzed using the Admiralty method to obtain the Mean High-Water Level (HHWL) and Mean Sea Level (MSL) of the Bengkalis coastal area. This analysis yielded the elevation of the MHWL and MSL are $2.6 \mathrm{~m}$ and $1.3 \mathrm{~m}$, respectively.

The wave design for simulation was the significant wave that was obtained from analysis using both Fastest Mile Windspeed method and Mean Mile Windspeed method. Each method was calculated using empiric and nomogram calculation. The result of the calculation is presented in Table 2.

Table 2. Calculation result of the wave design for simulation

\begin{tabular}{|c|c|c|c|c|}
\hline \multirow{2}{*}{ Methods } & \multicolumn{2}{|c|}{ Empiric calculation } & \multicolumn{2}{c|}{$\begin{array}{c}\text { Nomogram } \\
\text { calculation }\end{array}$} \\
\cline { 2 - 5 } & $\mathbf{H ~ ( m )}$ & $\mathbf{T ~ ( s )}$ & H (m) & T (s) \\
\hline $\begin{array}{c}\text { Fastest Mile } \\
\text { Windspeed }\end{array}$ & 0.457 & 2.429 & 0.46 & 2.42 \\
\hline $\begin{array}{c}\text { Mean Mile } \\
\text { Windspeed }\end{array}$ & 1.396 & 5.572 & 1.38 & 5.6 \\
\hline
\end{tabular}

Each calculation using empiric and nomogram shows a similar result for both Fastest Mile Windspeed method and Mean Mile Windspeed method. However, the significant wave from the analysis using the Mean Mile Windspeed Method shows the higher value than that of using Fastest Mile Windspeed Method. For further simulation, this study used a significant wave with height and period of 1.396 meters and 5.572 seconds respectively. 


\subsection{Wave simulation}

The results of the wave simulation for the six scenarios are presented in Fig. 5. Scenario Sc1, Sc-2, and Sc-3 are the wave simulation results for the high tide condition (HHWL) and Scenario Sc-4, Sc-5, and Sc-6 are the wave simulation results for the average tide condition (MSL). Scenario Sc-1 to Sc-3 is the extreme condition when the condition should be considered to protect the mangrove planting site. Table 3 shows the wave height and its velocity at $\mathrm{A}$ area where the plantation site is designed.

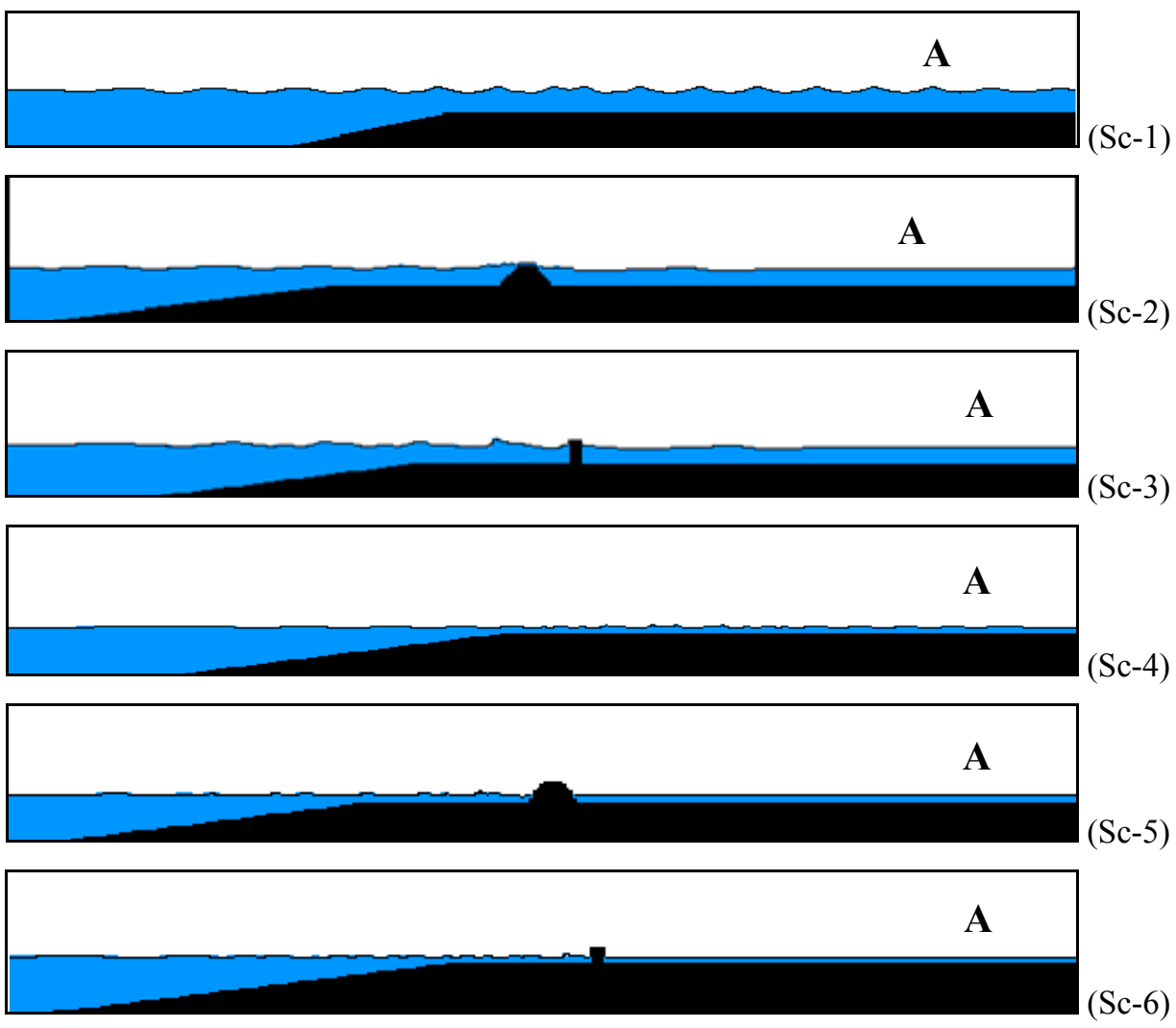

Fig. 5. Wave simulation results of the five scenarios.

The simulation result shows that in the HHWL condition, the wave height and wave velocity at the mangrove plantation site are about $1.12 \mathrm{~m}$ and $3.86 \mathrm{~m} / \mathrm{s}$ respectively in the case of the existing situation. In this case, the initial mangrove plantation cannot be applied because it will be destroyed by the wave. By applying breakwater both for rubble mound type and vertical wall type, the wave height and the wave velocity were reduced to $0.69 \mathrm{~m}$, $2.39 \mathrm{~m} / \mathrm{s}$ and $0.72 \mathrm{~m}, 2.31 \mathrm{~m} / \mathrm{s}$ respectively. It means that the wave energy was reduced to $40 \%$. In this case, the initial mangrove plantation can be applied because the wave will not destroy it. The rubble mound breakwater type has been used in another side of the field area and has proved that they can support effectively for the mangrove restoration, as presented in Fig. 6. The breakwater has functions not only to protect mangrove plantation site from the wave and current but also to trap the sediments behind the structure. The nutrient concentration, the $\mathrm{pH}$ value, and the salinity index because of sedimentation demonstrate that the site was conducive in establishing mangrove seedlings [9]. 
Table 3. Maximum velocity and wave height at the mangrove seeding area.

\begin{tabular}{|c|c|c|c|}
\hline Scenario & Velocity (m/s) & Wave height $(\mathbf{m})$ & Froude \\
\hline Sc-1 & 3.85 & 1.12 & 1.16 \\
\hline Sc-2 & 2.39 & 0.69 & 0.92 \\
\hline Sc-3 & 2.31 & 0.72 & 0.87 \\
\hline Sc-4 & 3.62 & 1.2 & 1.06 \\
\hline Sc-5 & 1.58 & 0.35 & 0.86 \\
\hline Sc-6 & 1.68 & 0.41 & 0.84 \\
\hline
\end{tabular}

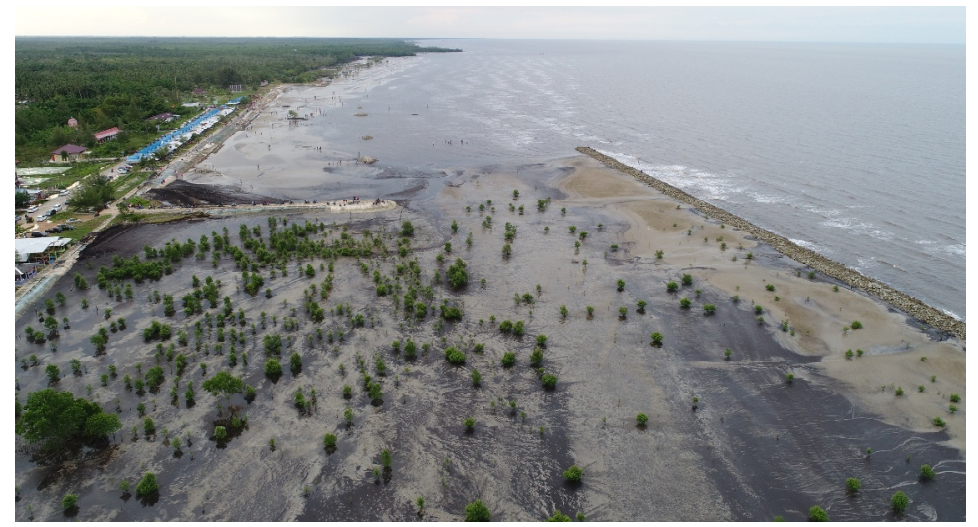

Fig. 6. Application of the rubble mound breakwater type to dampen wave energy for mangrove restoration activity.

\section{Conclusions}

In this paper, the application of detached breakwater for mangrove restoration in Bengkalis Island, Indonesia was simulated using numerical model CADMAS-SURF. The numerical simulation results show that the initial mangrove plantation site needs to be protected from wave and current using breakwater. Both types of breakwaters rubble mound and vertical wall were effective to reduce the wave energy about $40 \%$. The breakwater has functions not only to protect mangrove plantation site from the wave and current but also to trap the sediments behind the structure. The nutrient concentration, the $\mathrm{pH}$ value, and the salinity index because of sedimentation demonstrate that the site was conducive in establishing mangrove seedlings.

The authors would like to thank The Ministry of Research, Technology and Higher Education for the research grand of International Research Collaboration and Scientific Publication with contract number 290/UN.19.5.13/PP/2018.

\section{References}

1. J. Miettinen, C. Shi, S.C. Liew, Glob. Ecol. Conserv. 6 (2016)

2. F. Parish, A. Sirin, D. Charman, H. Joosten, T. Minayeva, M. Silvius, L. Stringer. 
Assessment on peatlands, biodiversity and climate change. (Global Environment Centre, Kuala Lumpur \& Wetlands International, Wageningen, 2008)

3. H. Kagawa, K. Yamamoto, M. Haidar, A. Kanno, Y. Akamatsu, M. Suzuki, S. Sutikno, N. Basir, M. Sekine. J. Environ. Eng. Res. 54, 7 (2017)

4. S. Sutikno, A. Sandhyavitri, M. Haidar, K. Yamamoto, Int. J. Environ. Sci. Dev. 7, 12 (2016)

5. S. Sutikno, Proc. of the 31st Annual Conference of Indonesian Association of Hydraulic Engineer (2014)

6. K. Yamamoto, M. Haidar, A. Kanno, M. Suzuki, Y. Akamatsu, N. Bashir, S. Sutikno, Muhardi, S. Satibi. Proc. of 15th International Peat Congress 2016 (2016)

7. K. Yamamoto, K. Miyara, T. Kobayashi, Y. Akamatsu, A. Kanno, N. Basir, H. Kagawa, S. Sutikno, J. Japan Soc. Civ. Eng. 73, 2 (2017)

8. E.C. Cruz, J.H. Primavera, J. Carlo, E.L. Santos, Engineering analysis for a mangrove planting site-towards a sustainable community-engaged coastal protection program in the Philippines. Available at http://www.irbnet.de/daten/iconda/CIB_DC26751.pdf (2011)

9. S. Motamedi, R. Hashim, R. Zakaria, K. Il Song, B. Sofawi, Sci. World J. 2014 (2014)

10. I. Wijatmiko, K. Murakami, J. Hydrodyn. 22, 5 (2010)

11. I. Wijatmiko, K. Murakami, Hydrodyn-theory model (2012)

12. F. Usman, A.D. Wicaksono, E. Setiawan, Rev. Eur. Stud. 8, 1 (2016)

13. F. Usman, K. Murakami, E.B. Kurniawan, Proc. Env. Sci. 20 (2014) 